\title{
Protective Effects of Zingiber zerumbet Ethyl Acetate Extract on Hydrogen Peroxide-Induced Damage of Red Blood Cells
}

(Kesan Perlindungan Ekstrak Etil Asetat Zingiber zerumbet pada Kerosakan Sel Darah Merah Aruhan Hidrogen Peroksida )

\author{
MOHD FuAd RaHMAT SAM, ASMAH HAMID, AHMAD RoHI GHAZALI, \\ SANTHANA RAJ LOUIS \& SITI BALKIS BUDIN*
}

\begin{abstract}
Zingiber zerumbet is widely used as therapeutic agent in traditional medicine and is reported to exert antioxidant activities. This study evaluated in vitro antioxidant potential of Z. zerumbet rhizome ethyl acetate extract on hydrogen peroxide $\left(\mathrm{H}_{2} \mathrm{O}_{2}\right)$-induced red blood cells (RBCs) damage; by measuring percentage of haemolysis, oxidative damage and morphological changes in treated RBCs. On a preliminary dose-response analysis, it was observed that incubation of RBCs with extract at doses of 50, 25, 12.5 and $6.25 \mu \mathrm{g} / \mathrm{mL}$ all had no significant effect on RBCs similar to NaCl control and $B H T$ (positive control), therefore, these concentrations were used in the subsequent study. The RBCs were pre-incubated with extract in the chosen concentrations, prior to treatment with $\mathrm{H}_{2} \mathrm{O}_{2}$. The results showed that only $6.25 \mu \mathrm{g} / \mathrm{mL}+\mathrm{H}_{2} \mathrm{O}_{2}$ group showed significantly $(\mathrm{p}<0.05)$ lower percentage of haemolysis and oxidative damage; indicated by low level of malondialdehyde (MDA) and protein carbonyls $(P C)$ compared to the $\mathrm{H}_{2} \mathrm{O}_{2}$ alone group. Electron microscopic examination further showed that pre-treatment with $6.25 \mu \mathrm{g} / \mathrm{mL}$ extract reduced the $\mathrm{H}_{2} \mathrm{O}_{2}$-induced morphological changes of RBCs. Phytochemical analysis of extract using Gas Chromatography Mass Spectrometry (GCMS) identified Zerumbone as the highest constituent compound (51.57\%) in this extract. In conclusion, this study indicated that $6.25 \mu \mathrm{g} / \mathrm{mL}$ ethyl acetate extract Z. zerumbet rhizome could efficiently protect RBCs against oxidative damage induced by $\mathrm{H}_{2} \mathrm{O}_{2}$ and this effects could possibly due the high constituent of Zerumbone.
\end{abstract}

Keywords: Haemolysis; lipid peroxidation; red blood cells; Zingiber zerumbet

ABSTRAK

Zingiber zerumbet digunakan secara meluas sebagai agen terapeutik dalam perubatan tradisi dan dilaporkan mempunyai sifat antioksidan. Kajian ini dinilai melalui potensi in vitro antioksidan ekstrak Z. zerumbet rizom etil asetat pada hidrogen peroksida $\left(\mathrm{H}_{2} \mathrm{O}_{2}\right)$-teraruh kerosakan sel-sel darah merah (RBCs); dengan mengukur peratus hemolisis, kerosakan oksidatif dan perubahan morfologi untuk RBCs terawat. Analisis awalan dos gerak balas, dicerapi bahawa inkubator RBCs dengan ekstrak pada dos 50, 25, 12.5 dan $6.25 \mu \mathrm{g} / \mathrm{mL}$ tidak menunjukkan kesan ketara RBCs yang menyerupai kawalan NaCl dan BHT (kawalan positif), maka kepekatan ini digunakan dalam kajian yang seterusnya. RBCs telah prainkubasi dengan ekstrak dalam kepekatan pilihan, sebelum dirawat dengan $\mathrm{H}_{2} \mathrm{O}_{2}$. Hasil kajian menunjukkan bahawa hanya kumpulan $6.25 \mu \mathrm{g} / \mathrm{mL}+\mathrm{H}_{2} \mathrm{O}_{2}$ menunjukkan signifikan $(\mathrm{p}<0.05)$ mengurangkan peratusan hemolisis dan kerosakan oksidatif; ditunjukkan oleh tahap rendah malondialdehid (MDA) dan protein karbonil (PC) berbanding kumpulan $\mathrm{H}_{2} \mathrm{O}_{2}$ sahaja. Pemeriksaan mikroskop elektron menunjukkan bahawa pra rawatan dengan ekstrak 6,25 $\mu \mathrm{g} / \mathrm{mL}$ mengurangkan morfologi $\mathrm{H}_{2} \mathrm{O}_{2}$-teraruh perubahan RBCs. Analisis fitokimia menggunakan Kromatografi Gas Jisim Spektroskopi (GCMS) mengenal pasti zerumbon sebagai yang bentuk sebatian tertinggi (51.57\%) di dalam ekstrak. Kesimpulannya, kajian ini menunjukkan bahawa $6.25 \mathrm{\mu g} / \mathrm{mL}$ ethil asetat rizom ekstrak Z. zerumbet secara cekap dapat melindungi RBCs daripada kerosakan oksidatif teraruh oleh $\mathrm{H}_{2} \mathrm{O}_{2}$ dan kesan ini boleh disebabkan oleh sebatian zerumbon yang tinggi.

Kata kunci: Hemolisis; pemperoksidaan lipid; sel-sel darah merah; Zingiber zerumbet

\section{INTRODUCTION}

Herbaceous plants contain numerous natural compounds with high medicinal value and health benefits. Medicine derived from plants is relatively safer, more tolerant to the patients, cheaper and always have a competitive advantage (Chong et al. 2018; Sen et al. 2009). Indeed, about $75-80 \%$ of the global population rely on natural products for their medicinal purposes (Kamboj 2000).
Therefore, there is a growing interest among the researchers to investigate scientific basis of the traditional medicinal plants.

Zingiber zerumbet or also known as lempoyang belongs to Zingiberaceae family and is widely cultivated throughout the tropics and South East Asia. Z. zerumbet rhizome, has been consumed as a traditional medicine for many years among Asian population as a cure 
for fever, stomach ache, sores and also to treat worm infestations (Bhuiyan et al. 2009; Somchit \& Shukriyah 2003). Pharmacologically, this rhizome also showed high antioxidant activities (Hamid et al. 2018) and contained various medicinal values including protection against paracetamol-induced hepatotoxicity (Hamid et al. 2011) and nephrotoxicity (Abd Hamid et al. 2012).

Red blood cells (RBCs) are regularly exposed to reactive oxygen species (ROS) and are among cells that are highly exposed to oxidative damage as results of continuous exposure to high concentration of oxygen and the presence of strong oxidative catalyst such as oxygen radicals. Furthermore, RBCs membrane is rich in polyunsaturated fatty acids (PUFA) making them extremely susceptible to lipid peroxidation and oxidative membrane damage (Konyalioglu \& Karamenderes 2005). According to Okoko and Ere (2012), hydrogen peroxide $\left(\mathrm{H}_{2} \mathrm{O}_{2}\right)$ among other type of ROS, is the main destructive agent in RBCs due to its ability to permeate across membranes. $\mathrm{H}_{2} \mathrm{O}_{2}$ also generates hydroxyl radicals that potentially cause RBCs damage (Okoko \& Ere 2012). $\mathrm{H}_{2} \mathrm{O}_{2}$ was previously reported as catalyst for protein and lipid oxidation that drive oxidative cell damage in RBCs (Srour et al. 2000). Oxidative damage contributes to senescence in normal RBCs, and leads to several functional and morphological disturbances such as advanced loss of deformability, reduced RBC lifespan and various RBCs disorder (Nagababu et al. 2003).

RBCs disorder caused by oxidative stress could be characterized either by an impaired antioxidant defence system or by increased production of ROS, which overwhelms the endogenous defence mechanism. Due to limited repair mechanisms, the inherent antioxidant system in RBCs may not provide adequate protection against oxidative damage and lead to membrane destruction and haemolysis. However, RBCs can be protected from such ROS-mediated damage by pharmacologically boosting the endogenous antioxidant system. Physiologically, the enzymatic antioxidant such as glutathione peroxidase (GPx), catalase and superoxide dismutase (SOD), as well as non-enzymatic antioxidant compounds including ascorbic acid, $\alpha$-tocopherols, reduced glutathione (GSH) and other thiols group protect the biomolecules including lipids and proteins from the oxidative damage (Anderson \& Phillips 1999; Tavazzi et al. 2000).

Oxidative damage of RBCs remains a primary etiology for RBCs disorders. Under any pathological circumstances, insufficiency of the endogenous antioxidants in RBCs can occur, thus the antioxidants are needed to be provided exogenously (Kiruthiga et al. 2007). Antioxidant from the nutrient sources are essential and it is believed that antioxidant supplements are good to prevent diseases that related to ROS activities. Given that $Z$. zerumbet extract is enriched with antioxidant activities (Ruslay et al. 2007), this study was undertaken to evaluate the protective role of $\mathrm{Z}$. zerumbet ethyl acetate extract against $\mathrm{H}_{2} \mathrm{O}_{2}$ induced RBCs oxidative damage in vitro.

\section{MATERIALS AND METHODS}

\section{PREPARATION OF Z. zerumbet EXTRACT}

Fresh rhizomes of $Z$. zerumbet from Temerloh, Pahang, Malaysia were deposited at the herbarium of Universiti Kebangsaan Malaysia (UKM), Bangi, Selangor, Malaysia (Voucher No. UKMB-29952). The cleaned rhizomes were chopped and dried for three days at room temperature; and were soaked in $n$-hexane twice for $48 \mathrm{~h}$, followed by ethyl acetate twice for $48 \mathrm{~h}$, respectively. Ethyl acetate extract was collected and evaporated using rotary evaporator as previously described (Hamid et al. 2011). The crude extract was stored at $4^{\circ} \mathrm{C}$ till further analysis. Prior to use, the $Z$. zerumbet extract was dissolved in $10 \% \mathrm{v} / \mathrm{v}$ dimethyl sulfoxide (DMSO) in normal saline.

\section{IDENTIFICATION OF EXTRACT COMPOUNDS BY GAS} CHROMATOGRAPHY-MASS SPECTROMETRY (GC-MS)

GC-MS was used for compound identification due to greatest sensitivity and specificity in identifying lipid soluble compounds which may benefit RBC membrane and was analyzed using available database and spectral libraries. Briefly, the extract was analyzed using GC-MS Shimadzu QP5050A equipped with a capillary column HP5.30m. For detection, an electron ionization system was operated in electron impact mode with an ionization energy of $70 \mathrm{eV}$. The helium gas was used as a carrier gas at a constant flow rate of $1 \mathrm{~mL} / \mathrm{min}$. The injector temperature was $250^{\circ} \mathrm{C}$ (mass analyser) while the oven temperature was programmed from $70-280^{\circ} \mathrm{C}$ at $6^{\circ} \mathrm{C} / \mathrm{min}$ with initial hold of $4 \mathrm{~min}$. Diluted sample was injected in the split mode with a split ratio and the spectrums of the unknown component were compared with the spectrum of the known components using data base of National Institute Standard and Technology (NIST) to ascertain the name, molecular weight and of the components.

\section{RED BLOOD CELLS PREPARATIONS}

The institutional animal ethic committee of Universiti Kebangsaan Malaysia (UKMAEC) had approved the animals handling model. Few studies showed a significant gender difference associated with oxidative stress. Oestrogen could have protective properties and that maybe involved (Bhatia et al. 2012). Therefore, in this study male Sprague-Dawley rats have been used in order to eliminate the oestrogen dominance role. Rats weighing between 200 and $240 \mathrm{~g}$ were housed in standard polypropylene cages and maintained at an ambient room temperature (12 h light/12 h dark). All rats had ad libitum access to standard laboratory rodent food and water. Rats were anesthetized with ketamine/xylazine cocktail and blood samples were obtained via orbital sinus, collected in heparinized tubes and centrifuged at $3000 \mathrm{rpm}, 4^{\circ} \mathrm{C}$ for $10 \mathrm{~min}$. RBCs were separated from the plasma and buffy coat and washed thrice with normal saline (PBS) before further analysis. 


\section{DOSE OPTIMIZATION}

Dose optimization was done using haemolysis assay (Tedesco et al. 2000). A total $100 \mu \mathrm{L}$ of $10 \%$ RBCs suspension was incubated for one hour in $100 \mu \mathrm{L}$ of different concentrations of extract $(6.25,12.5,25,50$, 100,200 and $400 \mu \mathrm{g} / \mathrm{mL}$ ) at $37^{\circ} \mathrm{C}$ in shaking water bath. The mixture was then centrifuged at $3000 \mathrm{rpm}$ for 10 min. The obtained supernatant was added into Drabkin solution and the haemolysis percentage was determined using spectrophotometer at $540 \mathrm{~nm}$ (Tedesco et al. 2000). Percentage of haemolysis was calculated for each group and compared against $50 \mu \mathrm{g} / \mathrm{mL}$ butylated hydroxytoluene (BHT) and $0.9 \% \mathrm{w} / \mathrm{v}$ normal saline $(\mathrm{NaCl})$, respectively. BHT was used as positive control with known ROS scavenging activity and $\mathrm{NaCl}$ was used as physiological saline for RBC suspension (vehicle control).

\section{EFFECT OF EXTRACT AGAINST $\mathrm{H}_{2} \mathrm{O}_{2}$ INDUCED DAMAGE}

To evaluate effects of extract on $\mathrm{H}_{2} \mathrm{O}_{2}$ induced haemolysis, RBCs suspension was pre-treated with the extract. The concentrations used in this study was based on the results of dose optimization. A total $100 \mu \mathrm{L}$ of $10 \%$ RBCs suspension was added into the glass tube, followed by $100 \mu \mathrm{L}$ of different concentrations of extract $(6.25,12.5,25,50 \mu \mathrm{g} /$ $\mathrm{mL}$ ) and placed at $37^{\circ} \mathrm{C}$ in shaking water bath. The mixture was incubated for one hour, centrifuged at $3000 \mathrm{rpm}$ at $4^{\circ} \mathrm{C}$ for $10 \mathrm{~min}$, and the RBCs were washed three times using PBS. The RBCs were then incubated with $100 \mu \mathrm{L} 2$ $\mathrm{mM} \mathrm{H}_{2} \mathrm{O}_{2}$ for $2 \mathrm{~h}$ to induce RBCs damage. After two hours of incubation, the mixture was centrifuged at $3000 \mathrm{rpm}$ at $4^{\circ} \mathrm{C}$ for $10 \mathrm{~min}$, and the supernatant taken for haemolysis determination as described previously and the RBCs pellet used for oxidative stress evaluation.

\section{OXIDATIVE STRESS}

The RBCs were used for antioxidant status as well as lipid peroxidation and protein oxidation analysis through identification of malondialdehyde (MDA) and protein carbonyl, respectively. Superoxide dismutase (SOD), glutathione peroxidase (GPX) and reduced glutathione (GSH) were measured for enzymatic and non-enzymatic antioxidant status. SOD and GPx activities as well as GSH level were measured according to the Beyer and Fridovich (1987), Ellman (1959), and Lawrence and Burk (1976), respectively. MDA was determined as the end product of lipid peroxidation based on method described by Hunter and Mohamed (1986) and protein carbonyl status was analyzed using modified Levine et al. (1990) method.

\section{MORPHOLOGICAL OBSERVATIONS}

Morphological observations were made using scanning electron microscope (SEM) according to Agrawal and Sultana (1993) with slight modification. RBCs were fixed with $3 \%(\mathrm{w} / \mathrm{v})$ glutaraldehyde for $1 \mathrm{~h}$ at room temperature. Then, the RBCs were placed on the microscopic cover glasses and washed with $\mathrm{NaCl}$ twice after $24 \mathrm{~h}$ later.
Samples were post-fixed with $1 \%$ (w/v) osmium tetraoxide for $1 \mathrm{~h}$ and dehydrated in ascending percentage of ethanol $(30 \%, 50 \%, 70 \%, 85 \%$, and $95 \%$; v/v) in $100 \%$ acetone. Subsequently, all samples were dried with $\mathrm{CO}_{2}$, coated with gold-palladium, and examined under SEM (Tecnai G2, FEI, USA). The data was analysed based on the study done by Taib et al. (2009) with some modification.

\section{STATISTICAL ANALYSIS}

The data were expressed as mean \pm standard error of mean (S.E.M.). Statistical analysis was performed using Statistical Package for the Social Sciences (SPSS) version 18. The significant differences between groups were determined using one-way analysis of variance (ANOVA) followed by Post-hoc Tukey test with $p<0.05$ considered as statistically significant difference.

\section{RESULTS}

\section{PHYTOCHEMICAL IDENTIFICATION}

The presence of phytochemical constituents of $Z$. zerumbet extract is shown in Figure 1 and Table 1 based on gas chromatographic analysis. Compound identification was done by comparing with NIST library data of the peaks (Hossain et al. 2005; Jang et al. 2005). Various bioactive compounds were identified in the extract which majorly contains zerumbone $(2,6,10-$ Cycloundecatrien-1-one, 2,6,9,9-tetramethyl-, (E,E,E)-) at the percentage of $51.57 \%$ (Table 1).

\section{DOSE OPTIMIZATION}

Figure 2 demonstrates that the high doses of $Z$. zerumbet extract including 400, 200 and $100 \mu \mathrm{g} / \mathrm{mL}$ increased the percentage of haemolysis compared to the normal control $(\mathrm{NaCl})$ and BHT group $(p<0.05)$. However, no significant differences were found for the percentage of haemolysis between low doses of $Z$. zerumbet extract which were at $50,25,12.5$ and $6.25 \mu \mathrm{g} / \mathrm{mL}$ compared to $\mathrm{NaCl}$ and BHT group. Therefore, based on the haemolysis percentage, four doses of $Z$.zerumbet extract $(50,25,12.5$ and $6.25 \mu \mathrm{g} / \mathrm{mL})$ were chosen for subsequent haemolysis, oxidative stress and morphological evaluation.

\section{EFFECTS OF ETHYL ACETATE EXTRACT OF Z. zerumber PRE-TREATMENT ON HAEMOLYSIS PERCENTAGE}

Table 2 shows the effects of ethyl acetate extract of $Z$. zerumbet on the haemolysis percentage of RBCs induced by $\mathrm{H}_{2} \mathrm{O}_{2}$. The haemolysis percentage in $\mathrm{H}_{2} \mathrm{O}_{2}$ group and all $Z$. zerumbet pre-treated groups were significantly higher compared to $\mathrm{NaCl}$ group ( $p<0.05$ for all). Among all $Z$. zerumbet pre-treated groups, RBCs treated with $6.25 \mu \mathrm{g} /$ $\mathrm{mL} Z$. zerumbet, however, showed lowest haemolysis percentage and is the only group with significantly lower haemolysis percentage compared to $\mathrm{H}_{2} \mathrm{O}_{2}$ group. On the other hand, group with $50 \mu \mathrm{g} / \mathrm{mL} \mathrm{Z}$. zerumbet showed 


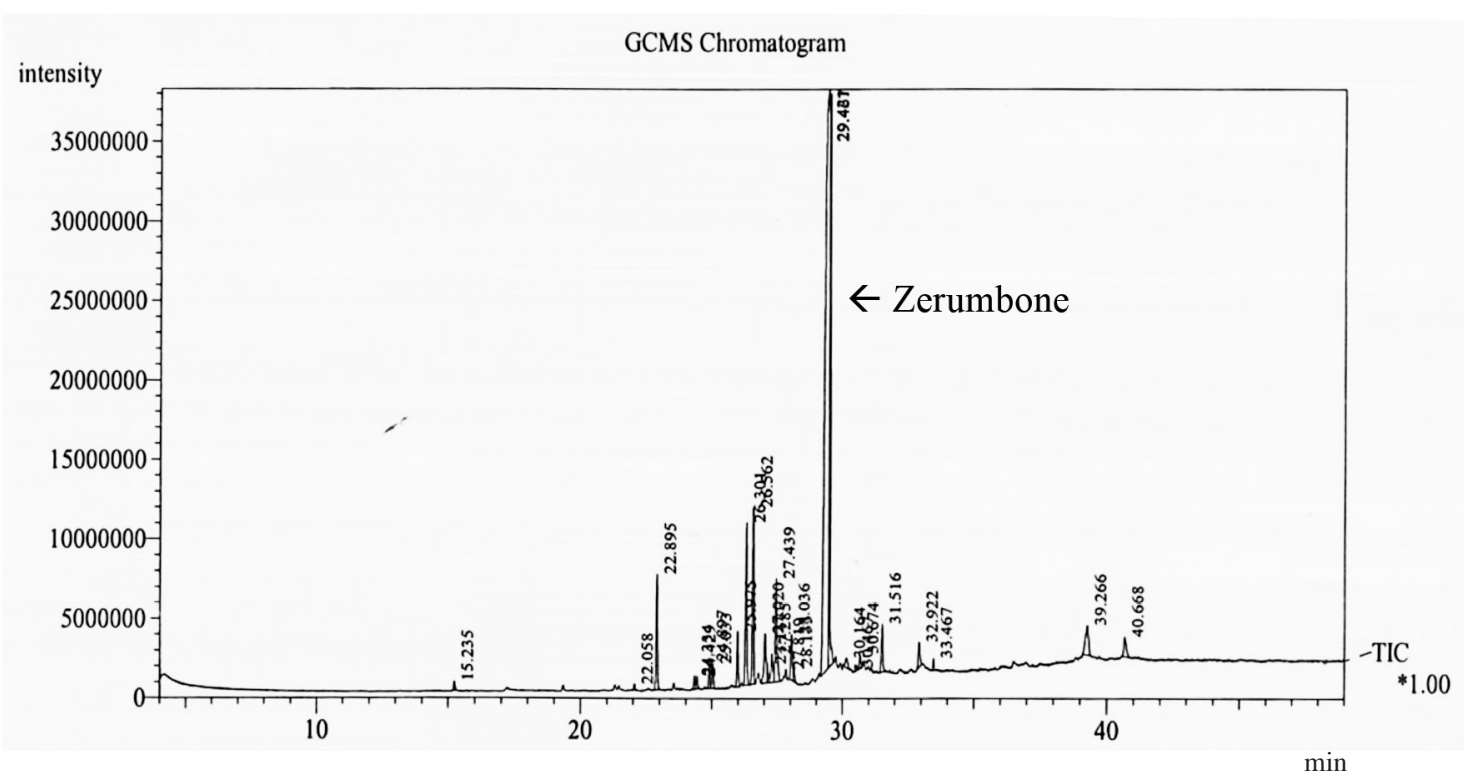

FIGURE 1. GC-MS chromatogram analysis of the ethyl acetate extract of $Z$. zerumbet

TABLE 1 . The chemical constituents in ethyl acetate extract of $Z$. zerumbet by comparing with NIST library data of the peaks as reported in Hossain et al. (2005) and Jang et al. (2005)

\begin{tabular}{cclccc}
\hline No & $\begin{array}{c}\text { Retention time } \\
(\mathrm{RT})\end{array}$ & The Probably Compound & $\begin{array}{c}\text { Molecular } \\
\text { Weight }\end{array}$ & $\begin{array}{c}\text { Molecular } \\
\text { Formula }\end{array}$ & $\begin{array}{c}\text { Abundance } \\
(\%)\end{array}$ \\
\hline 1 & 22.895 & Humulene & 204 & $\mathrm{C}_{15} \mathrm{H}_{24}$ & 3.20 \\
2 & 25.975 & Caryophyllene oxide & 220 & $\mathrm{C}_{15} \mathrm{H}_{24} \mathrm{O}$ & 1.45 \\
3 & 26.301 & 1,2-Dihydropyridine,1-(1-oxobutyl)- & 151 & $\mathrm{C}_{9} \mathrm{H}_{13} \mathrm{NO}$ & 4.75 \\
4 & 26.562 & Spiro (4,5) decane & 138 & $\mathrm{C}_{10} \mathrm{H}_{18}$ & 5.09 \\
5 & 27.020 & 4,8,12,16-Octadecatetraen-1-ol,4,9,13,17-tetramethyl- & 318 & $\mathrm{C}_{22} \mathrm{H}_{38} \mathrm{O}$ & 2.20 \\
6 & 27.285 & 1,5,9,11-Tridecatetraene, 12-methyl-,(E,E)- & 190 & $\mathrm{C}_{14} \mathrm{H}_{22}$ & 1.26 \\
7 & 27.439 & 2-Naphthalenemethanol & 222 & $\mathrm{C}_{15} \mathrm{H}_{26} \mathrm{O}$ & 4.01 \\
8 & 28.036 & Verbenol & 152 & $\mathrm{C}_{10} \mathrm{H}_{16} \mathrm{O}$ & 1.61 \\
9 & 29.421 & 2,6,10-Cycloundecatrien-1-one, 2,6,9,9-tetramethyl-, (E,E,E)- & 218 & $\mathrm{C}_{15} \mathrm{H}_{22} \mathrm{O}$ & 51.57 \\
10 & 29.467 & 1-(hexahydropyrrolizin-3-ylidene)-3-3-dimethylbutan-2-one & 207 & $\mathrm{C}_{13} \mathrm{H}_{21} \mathrm{NO}^{2}$ & 14.60 \\
11 & 31.516 & 4,8,13-Cyclotetradecatriene-1,3-diol,1,5,9-trimethyl-12-(1- & 306 & $\mathrm{C}_{20} \mathrm{H}_{34} \mathrm{O}_{2}$ & 1.51 \\
& & methylethyl)- & & 296 & $\mathrm{C}_{20} \mathrm{H}_{24} \mathrm{O}_{2}$ \\
\hline
\end{tabular}

significantly higher haemolysis percentage compared to $\mathrm{H}_{2} \mathrm{O}_{2}$ group $(\mathrm{p}<0.05)$. Meanwhile, all extract pre-treated groups had significantly higher haemolysis percentage compared with $\mathrm{BHT}+2 \mathrm{mM} \mathrm{H}_{2} \mathrm{O}_{2}$.

\section{LIPID PEROXIDATION AND PROTEIN OXIDATION}

To further provide evidence of the effect of Z. zerumbet, results of lipid peroxidation and protein oxidation are shown in Figures 3 and 4, respectively. The MDA and protein carbonyl level in $\mathrm{H}_{2} \mathrm{O}_{2}$ group and all $Z$. zerumbet pre-treated groups were significantly higher compared to $\mathrm{NaCl}(p<0.05)$. However, only $6.25 \mu \mathrm{g} / \mathrm{mL} Z$. zerumbet extract showed significantly lower level of MDA and protein carbonyl compared with $\mathrm{H}_{2} \mathrm{O}_{2}$ group $(p<0.05)$. Contrarily, group pre-treated with $50 \mu \mathrm{g} / \mathrm{mL} Z$. zerumbet extract showed significantly higher MDA and protein carbonyl level compared to the $\mathrm{H}_{2} \mathrm{O}_{2}$ group $(p<0.05)$. Even though all the extract pre-treated groups showed significantly higher MDA and protein carbonyl level compared with $\mathrm{BHT}+2 \mathrm{mM} \mathrm{H}_{2} \mathrm{O}_{2}$ group, the group pre-treated with $6.25 \mu \mathrm{g} / \mathrm{mL} \mathrm{Z}$. zerumbet $+2 \mathrm{mM} \mathrm{H}_{2} \mathrm{O}_{2}$ tended to have closer value to BHT.

\section{ENZYMATIC AND NON-ENZYMATIC ANTIOXIDANT STATUS}

Figures 5,6 and 7 show that SOD and GPX activities as well as GSH level of $\mathrm{H}_{2} \mathrm{O}_{2}$ group was significantly reduced compared to the $\mathrm{NaCl}$ group $(p<0.05)$. A similar trend was 


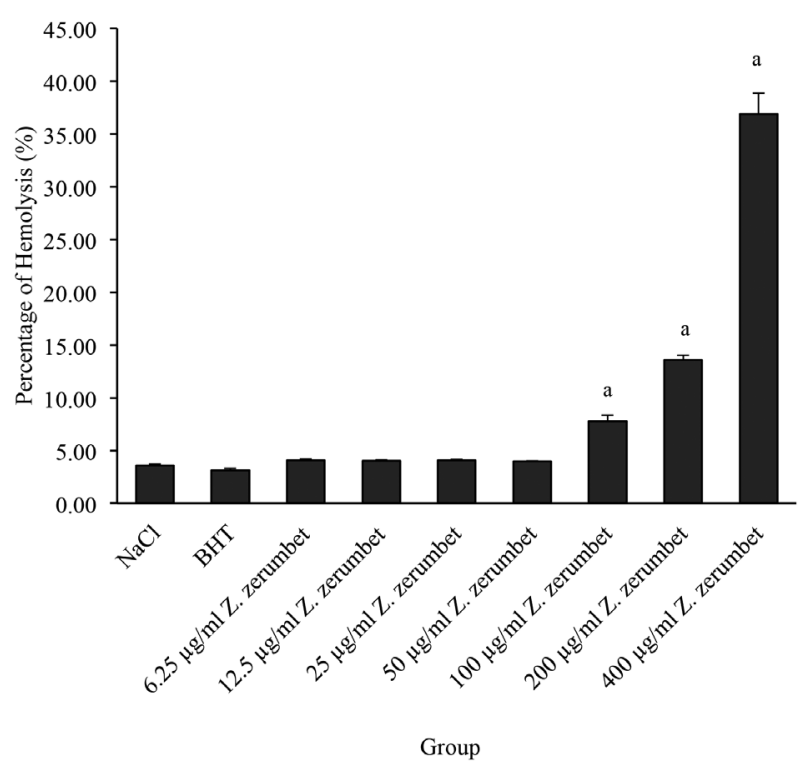

FIGURE 2. Dose optimization of ethyl acetate extract of Z. zerumbet based on percentage hemolysis. The values are expressed as mean

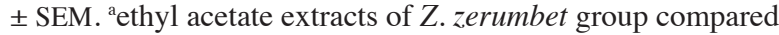
to $\mathrm{NaCl}$ group $(p<0.05)$

TABLE 2. The effects of ethyl acetate extract of $Z$. zerumbet on the hemolysis percentage of RBCs. The values are expressed as means \pm SD. ${ }^{\text {a }}$ ethyl acetate extracts of $Z$. zerumbet group compared to $\mathrm{NaCl}$ group $(p<0.05)$. ${ }^{\mathrm{b}}$ ethyl acetate extracts of $Z$. zerumbet group compared to $\mathrm{H}_{2} \mathrm{O}_{2}$ group $(p<0.05)$. ${ }^{c}$ ethyl acetate extracts of $Z$. zerumbet group compared to $\mathrm{BHT}+\mathrm{H}_{2} \mathrm{O}_{2}$ group $(p<0.05)$

\begin{tabular}{lc}
\hline Group & $\begin{array}{c}\text { Percentage of } \\
\text { hemolysis }(\%)\end{array}$ \\
\hline $\mathrm{NaCl}$ & $2.8 \pm 0.3$ \\
$2 \mathrm{mM} \mathrm{H} \mathrm{O}_{2}$ & $21.0 \pm 2.0^{\mathrm{a}}$ \\
$\mathrm{BHT}+2 \mathrm{mM} \mathrm{H} \mathrm{O}_{2}$ & $3.1 \pm 0.3^{\mathrm{b}}$ \\
$6.25 \mu \mathrm{g} / \mathrm{mL} \mathrm{Z}$. zerumbet $+2 \mathrm{mM} \mathrm{H}_{2} \mathrm{O}_{2}$ & $7.2 \pm 1.0^{\mathrm{a}, \mathrm{b}, \mathrm{c}}$ \\
$12.5 \mu \mathrm{g} / \mathrm{mL}$ Z. zerumbet $+2 \mathrm{mM} \mathrm{H}_{2} \mathrm{O}_{2}$ & $18.5 \pm 1.5^{\mathrm{a}, \mathrm{c}}$ \\
$25 \mu \mathrm{mL}$ Z. zerumbet $+2 \mathrm{mM} \mathrm{H}_{2} \mathrm{O}_{2}$ & $20.4 \pm 1.7^{\mathrm{a}, \mathrm{c}}$ \\
$50 \mu \mathrm{g} / \mathrm{mL}$ Z. zerumbet $+2 \mathrm{mM} \mathrm{H}_{2} \mathrm{O}_{2}$ & $23.8 \pm 1.8^{\mathrm{a}, \mathrm{b}, \mathrm{c}}$ \\
\hline
\end{tabular}

also observed in BHT $+\mathrm{H}_{2} \mathrm{O}_{2}$ group and all Z. zerumbet pre-treated groups. $Z$. zerumbet pre-treatment did not significantly affect SOD and GPX activities as well as GSH levels in all pre-treated groups compared to $\mathrm{H}_{2} \mathrm{O}_{2}$ group.

\section{MORPHOLOGICAL OBSERVATIONS}

SEM images depicting effects of $Z$. zerumbet extract on RBCs incubated with $\mathrm{H}_{2} \mathrm{O}_{2}$ are shown in Figure 8. The RBCs of $\mathrm{H}_{2} \mathrm{O}_{2}$ group showed significant morphological changes with distinct echinocyte formation. The $\mathrm{BHT}+2 \mathrm{mM} \mathrm{H}_{2} \mathrm{O}_{2}$ showed very mild morphological changes. Similarly, minimal morphological changes were observed in 6.25 $\mu \mathrm{g} / \mathrm{mL} Z$. zerumbet $+2 \mathrm{mM} \mathrm{H}_{2} \mathrm{O}_{2}$ group and most of the cells maintained their normal smooth biconcave shape. Consistent with this, Figure 9 shows that among all extract pre-treated groups, $6.25 \mu \mathrm{g} / \mathrm{mL} \mathrm{Z}$. zerumbet $+2 \mathrm{mM} \mathrm{H}_{2} \mathrm{O}_{2}$

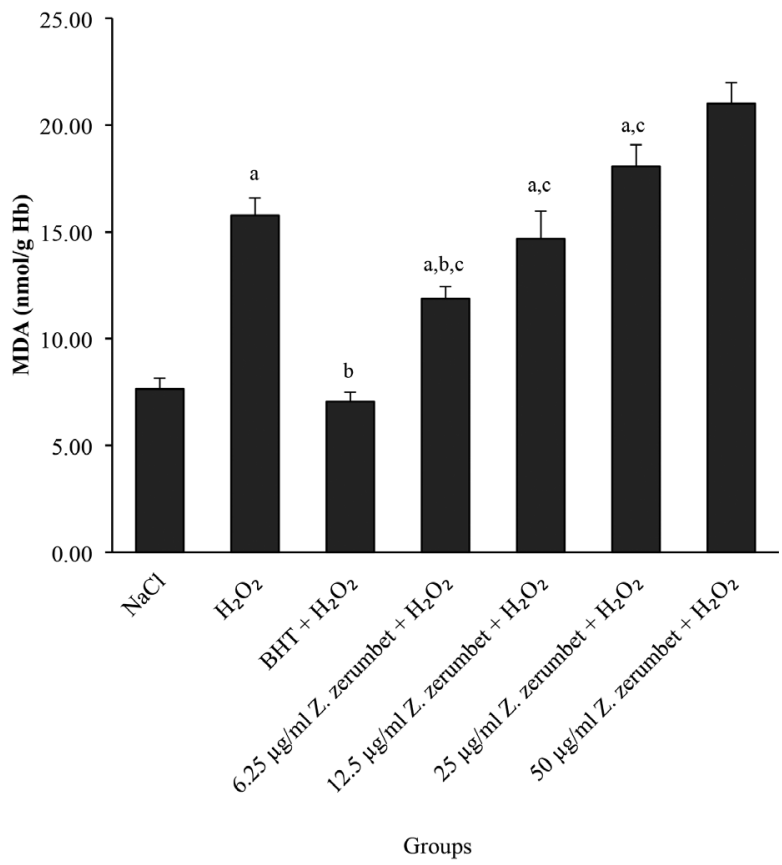

FIGURE 3. Effects of ethyl acetate extract of $Z$. zerumbet on MDA levels of RBCs The values are expressed as mean \pm SEM. aethyl acetate extracts of $Z$. zerumbet group compared to $\mathrm{NaCl}$ group

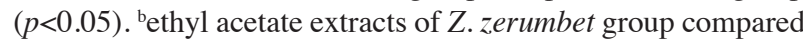
to $\mathrm{H}_{2} \mathrm{O}_{2}$ group $(p<0.05)$. 'ethyl acetate extracts of $Z$. zerumbet group compared to $\mathrm{BHT}+\mathrm{H}_{2} \mathrm{O}_{2}$ group $(p<0.05)$

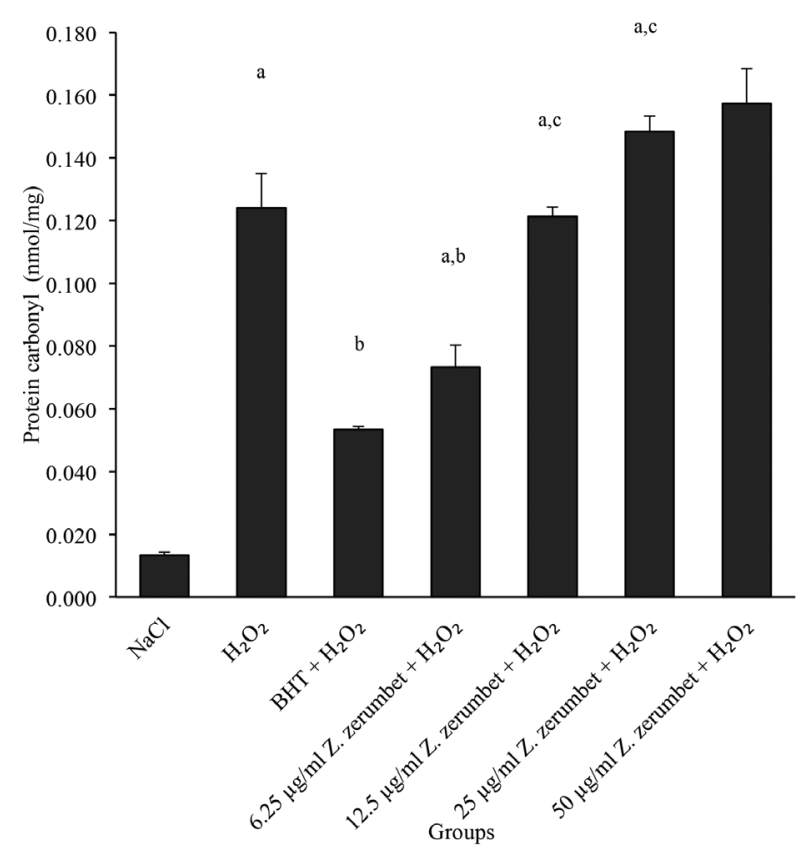

FIGURE 4. Effects of ethyl acetate extract of Z. zerumbet on protein carbonyl levels of RBCs. The values are expressed as mean \pm SEM. a ethyl acetate extracts of $Z$. zerumbet group compared to

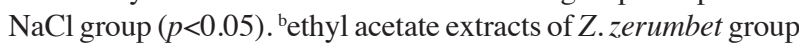
compared to $\mathrm{H}_{2} \mathrm{O}_{2}$ group $(p<0.05)$. cethyl acetate extracts of $Z$. zerumbet group compared to $\mathrm{BHT}+\mathrm{H}_{2} \mathrm{O}_{2}$ group $(p<0.05)$ 


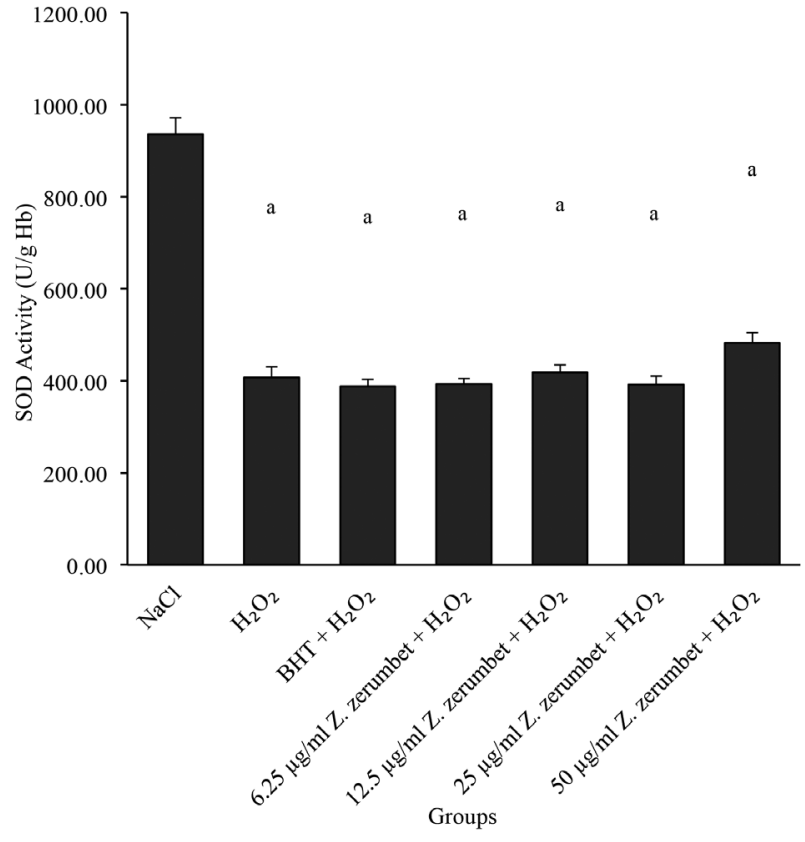

FIGURE 5. Effects of ethyl acetate extract of $Z$. zerumbet on SOD activity of RBCs The values are expressed as mean \pm

SEM. aethyl acetate extracts of $Z$. zerumbet group compared to $\mathrm{NaCl}$ group $(p<0.05)$

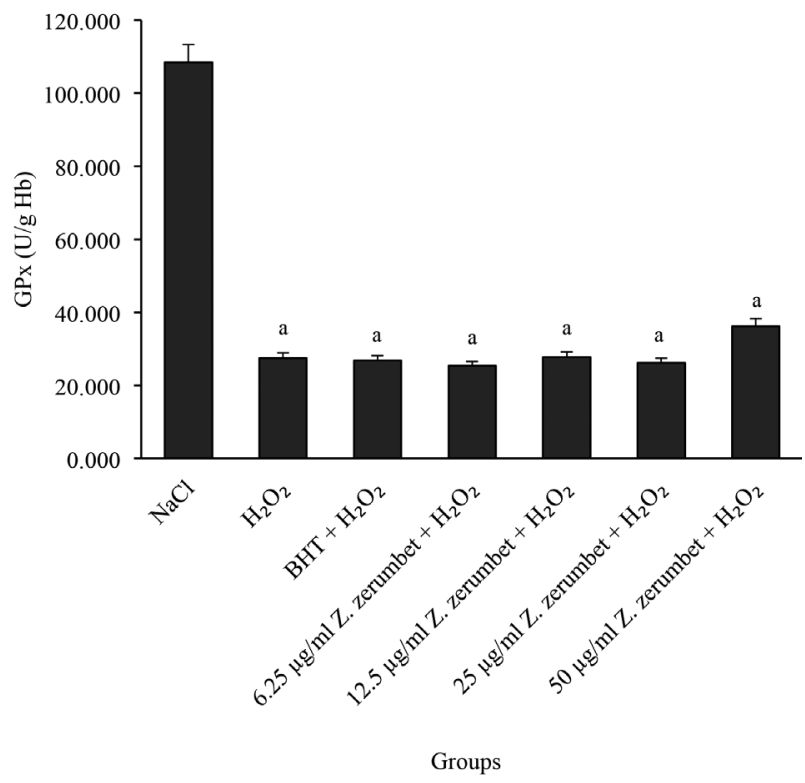

FIGURE 6. Effects of ethyl acetate extract of Z. zerumbet on GPx activity of RBCs. The values are expressed as mean \pm SEM. aethyl acetate extracts of $Z$. zerumbet group compared to $\mathrm{NaCl}$ group $(p<0.05)$

group had the lowest number of echinocyte formation and it is significantly lower compared with the $\mathrm{H}_{2} \mathrm{O}_{2}$ group.

\section{DISCUSSION}

The presence of various phytochemicals and the potential antioxidant properties including polyphenols

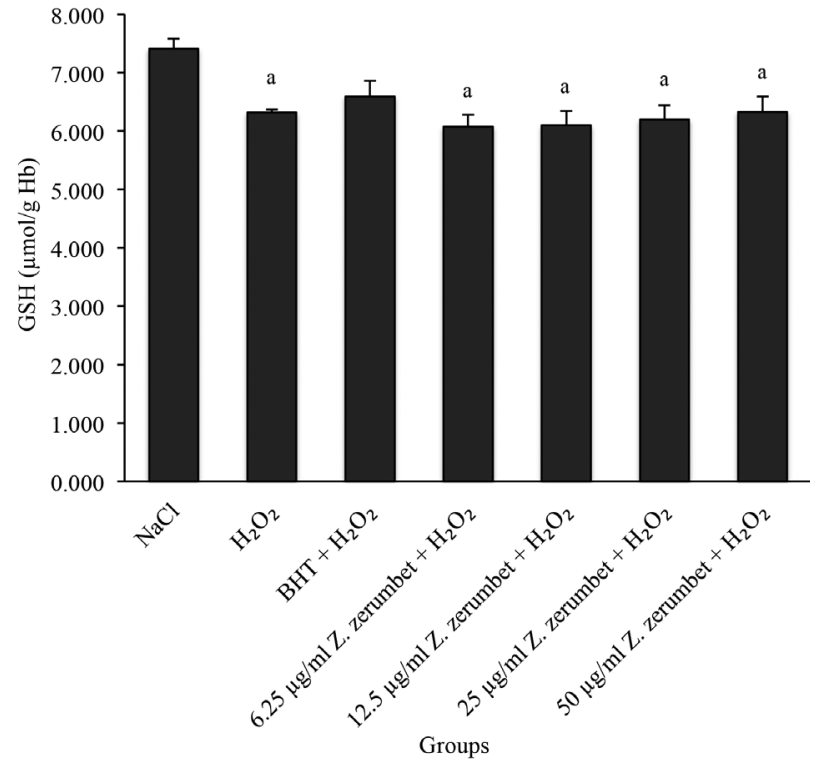

FIGURE 7. Effects of ethyl acetate extract of $Z$. zerumbet on GSH levels of RBCs. The values are expressed as mean \pm SEM. aethyl acetate extracts of $Z$. zerumbet group compared to $\mathrm{NaCl}$ group $(p<0.05)$
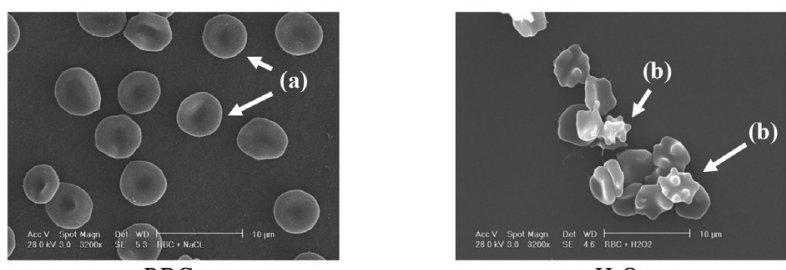

RBCs $\mathrm{H}_{2} \mathrm{O}_{2}$

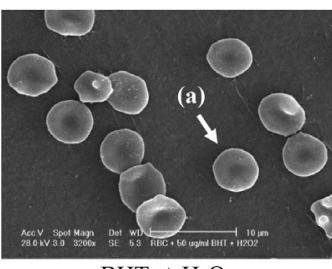

$\mathrm{BHT}+\mathrm{H}_{2} \mathrm{O}_{2}$

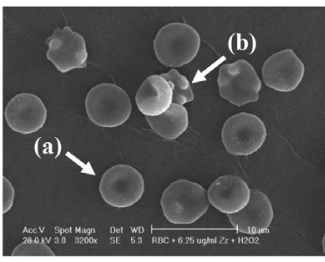

$6.25 \mu \mathrm{g} / \mathrm{mL}$ Z. zerumbet $+\mathrm{H}_{2} \mathrm{O}_{2}$

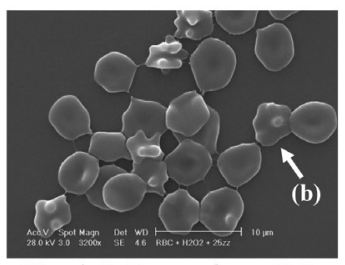

$25 \mu \mathrm{g} / \mathrm{mL}$ Z. zerumbet $+\mathrm{H}_{2} \mathrm{O}_{2}$

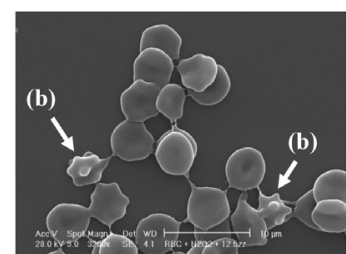

$12.5 \mu \mathrm{g} / \mathrm{mL}$ Z. zerumbet $+\mathrm{H}_{2} \mathrm{O}_{2}$

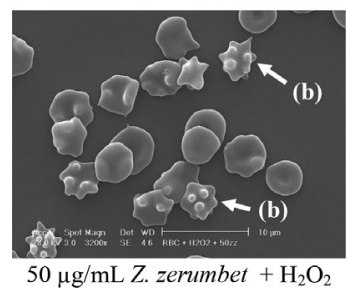

$50 \mu \mathrm{g} / \mathrm{mL}$ Z. zerumbet $+\mathrm{H}_{2} \mathrm{O}_{2}$
FIGURE 8. Scanning electron micrograph of Z. zerumbet in various study groups, (a) Normal RBCs (biconcave) and (b) Echinocyte $(\times 3200)$ 


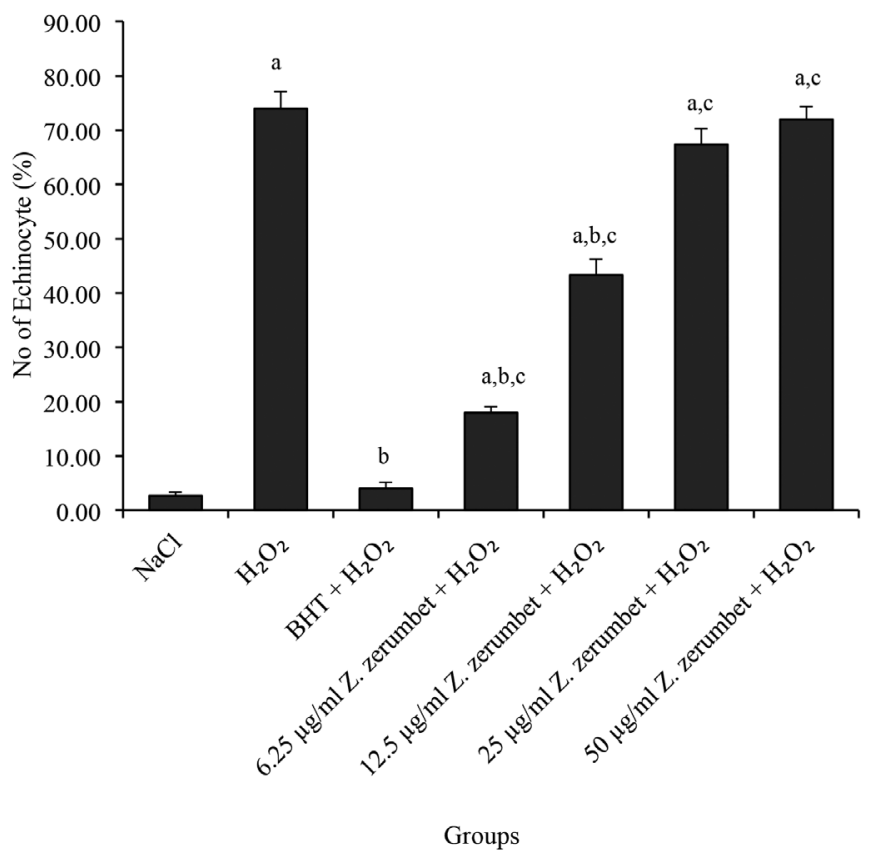

FIGURE 9. Effects of ethyl acetate extract of Z. zerumbet on echinocyte formation. The values are expressed as mean \pm SEM. aethyl acetate extracts of $Z$. zerumbet group compared to $\mathrm{NaCl}$ group

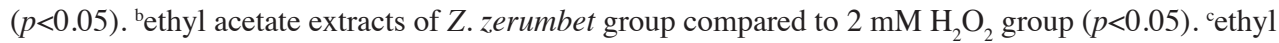
acetate extracts of $Z$. zerumbet group compared to BHT $+\mathrm{H}_{2} \mathrm{O}_{2}$ group $(p<0.05)$

and flavonoids in the medicinal plants could contribute to their valuable health benefits. The present study showed the presence of twelve compounds in the ethyl acetate extract of $Z$. zerumbet and the major constituent was zerumbone. This finding supports past studies that also reported zerumbone as the main compound in the rhizomes of Z. zerumbet (da Silva et al. 2018; Rashid \& Pihie 2005) Zerumbone is a compound derived from several plant species of the Zingiberaceae family and it has been reported to possess multiple medicinal effects, such as antiproliferative against cancer cells, antioxidant and anti-inflammatory activities (Rashid \& Pihie 2005). Several lines of evidence showed zerumbone has free radical scavenging activity and attenuates oxidative stress. Recently $Z$. zerumbet ethyl acetate extract was also documented to have hepatoprotective effects on paracetamol-induced hepatotoxicity in rats and it was believed that the protective effects are due to the presence of high zerumbone composition (Hamid et al. 2018). Abdul Hamid et al. (2012) also reported that administration of $Z$. zerumbet ethyl acetate extract protected against paracetamol-induced nephrotoxicity in rats.

Determination of the optimum dose for further biochemical analysis is important to ensure that the chosen dose has no observable adverse effect (Holland-Letz \& Kopp-Schneider 2015). Incubation of RBCs with the high doses of $Z$. zerumbet extract increased the percentage of haemolysis likely due to the possible cytotoxic effects of certain compounds in the extract (Tourino et al. 2008). This study is in line with study by Nag et al. (2013) showing that $Z$. zerumbet extract were found to be cytotoxic at higher concentrations, whereby the number of viable blood lymphocyte cells decreased significantly at concentrations $300 \mu \mathrm{g} / \mathrm{mL}$ and above. However, in this study the lower doses of $Z$. zerumbet extract ranged from 6.25 to $50 \mu \mathrm{g} / \mathrm{mL}$ did not cause significant difference in haemolysis compared to control group; therefore, these doses are safe and do not cause adverse effects to RBC thus were selected for further efficacy study.

RBCs are the most abundant cells in the blood, enucleated, has no organelles and protein synthesizing activities, therefore, become a convenient cellular model system to study toxicant-induced oxidative damage (Qasim \& Mahmood 2015). Several parameters were then determined to see if ethyl acetate extract could mitigate $\mathrm{H}_{2} \mathrm{O}_{2}$-induced oxidative stress and cell injury in RBC. In vitro haemolysis assay of RBCs is a very reliable and simple model for studying free radical induced oxidative damage (Banerjee et al. 2008; Qasim \& Mahmood 2015). Treatment of RBCs with $\mathrm{H}_{2} \mathrm{O}_{2}$ resulted in high percentage of haemolysis but this was prevented by pre-treatment of cells with ethyl ecetate extrat of $Z$.zerumbet. Findings from this study suggested that lower dose supplementation of $Z$. zerumbet extract $(6.25 \mu \mathrm{g} / \mathrm{mL})$ is effective in protecting RBCs from haemolysis induced by $\mathrm{H}_{2} \mathrm{O}_{2}$. However, pretreatment with a higher concentration of extract causes more significant haemolysis in dose-dependent manner. The lowest dose leads to beneficial effect whereas the high doses may result in harmful effects; indicating Z. zerumbet has a biphasic effect on RBC haemolysis. Although it is not known what mechanisms underlie such observations, it could be speculated that $Z$. zerumbet has a 
dual antioxidant/pro-oxidant effect of from its compounds, and their capacity to either scavenge or generate radicals may depend on the environment (Chakraborthy et al. 2014).

Disruption of redox homeostasis, resulting from increased ROS generation or compromised endogenous antioxidant system is a basic mechanism of various diseases. $\mathrm{H}_{2} \mathrm{O}_{2}$ is non-radical ROS with excellent membrane permeability and it is widely recognized as a mediator and inducer of oxidative stress. Importantly, $\mathrm{H}_{2} \mathrm{O}_{2}$ was shown to oxidize poly-unsaturated fatty acids (PUFAs) and proteins in cell membrane and accelerate cell damage in various settings. Lipids and protein play crucial role in maintaining the structural integrity and physiological function of cells. Uncontrolled lipid peroxidation of cellular membranes alters its physical properties and leads to disruption of cellular proteins and nucleic acids (Gaschlera \& Stockwell 2017).

Consistent with these, analysis of RBCs for lipid peroxidation and protein oxidation showed $\mathrm{H}_{2} \mathrm{O}_{2}$ increased both MDA and protein carbonyl level after incubation and thus may be responsible for observed high haemolysis percentage. The lowest dose of $Z$. zerumbet however, significantly inhibited the oxidation of both lipid and protein by $\mathrm{H}_{2} \mathrm{O}_{2}$. The RBCs treated with $6.25 \mu \mathrm{g} / \mathrm{mL}$ extract showed lowest level of MDA and protein carbonyl whereas the higher concentration caused significantly higher level of oxidation in dose-dependent manner. $\mathrm{H}_{2} \mathrm{O}_{2}$-induced lipid peroxidation was decreased in RBCs treated with $6.25 \mu \mathrm{g} / \mathrm{mL}$ extract indicating that ethyl acetate extract at lower dose can protect membrane lipid oxidation. Studies have also demonstrated that haemolysis is a consequence of lipid peroxidation. MDA can cross-link proteins and phospholipids resulting in membrane dysfunction, haemolysis and diminished cell survival (Cimen 2008).

ROS can also lead to protein oxidation that produces carbonyl groups that impairs protein function. Accumulation of protein carbonyls often results from oxidative damage to the protein backbone, direct oxidation of amino acid side chains or binding of aldehydes produced from lipid peroxidation. $\mathrm{H}_{2} \mathrm{O}_{2}$ increased carbonyl content in this study indicating elevated protein oxidation in the RBCs and interestingly ethyl acetate extract was shown to protect against protein oxidation as shown by markedly reduced protein carbonyl level in pre-treated groups.

Oxidative damage to RBCs may be implicated in haemolysis and often is associated with deficient RBC antioxidant system. In this study, although RBCs were supplemented with different concentrations of Z zerumbet, it did not restore the activities or prevent depletion of endogenous antioxidants. As RBCs are non-nucleated cells, they are unable to synthesize protein and are incapable of replacing damaged components. They have to rely on the proteins synthesized earlier in their production at bone marrow to protect them against ROS (Clemens \& Waller 1987; Hattangadi \& Lodish 2007). Although this study demonstrated that the enzymatic and non-enzymatic antioxidants RBCs were fully utilized to protect the damage induced by $\mathrm{H}_{2} \mathrm{O}_{2}$ it was noted $Z$. zerumbet does not necessarily boost endogenous antioxidant system to prevent oxidative damage and its protective effect may be due to direct ROS scavenging effect.

Haemolysis activated by oxidative insult leads to alteration in shape of RBCs. The scanning electron microscopy results strongly support our biochemical studies, whereby electron microscopic observations showed that $\mathrm{H}_{2} \mathrm{O}_{2}$ caused a morphological alteration and significant conversion of RBCs from biconcave disc-shape to echinocyte form. The increase in echinocyte-formed RBCs by exposure to $\mathrm{H}_{2} \mathrm{O}_{2}$ is likely a consequence of polymerisation and cross-linking reactions of membrane components associated with oxidant stress (Srour et al. 2000). This morphological effect of the oxidant was consistent with the findings by Qasim and Mahmood (2015).

The ethyl acetate extract of $Z$. zerumbet was very effective in protecting erythrocytes from oxidantinduced damage and greatly restored the erythrocyte cell morphology. Our findings showed that the lower dose of the extract significantly maintained the morphological integrity of the RBCs that exposed to the $\mathrm{H}_{2} \mathrm{O}_{2}$ and considerably reduced the deleterious capacity of $\mathrm{H}_{2} \mathrm{O}_{2}$ to induce RBCs haemolysis. The lowest dose of $Z$. zerumbet extract demonstrated significant protection against lipid peroxidation, protein oxidation and haemolysis in the RBCs exposed to $\mathrm{H}_{2} \mathrm{O}_{2}$. The ability of the lowest doses of $Z$. zerumbet extract in protecting the oxidative stress could be the reasons of retaining its morphological integrity. The protective effect of ethyl acetate extract could possibly due to the presence of zerumbone. This could possibly also due to the presence of different phytochemicals which may have acted in synergy.

\section{CONCLUSION}

It can be suggested that the ethyl acetate extract of $Z$. zerumbet at lowest dose has the capability to protect RBCs from haemolysis, lipid peroxidation, protein oxidation and morphological changes of RBCs induced by $\mathrm{H}_{2} \mathrm{O}_{2}$. However, the possible compound that is responsible for this antioxidant action is still unknown. There might be an interaction or synergy between the extract of $Z$. zerumbet and the antioxidants system, thus showing the potential in protecting the RBCs from oxidative damage induced by $\mathrm{H}_{2} \mathrm{O}_{2}$. The ethyl acetate extract of $Z$. zerumbet may offer new significant health benefits towards the pathological conditions that are closely linked to free radicals.

\section{ACKNOWLEDGEMENTS}

We would like to acknowledge Universiti Kebangsaan Malaysia (UKM) for the financial support for this project. We would also like to thank the Director of Institute of Medical Research for the permission in using the electron microscopic facilities. 


\section{REFERENCES}

Abd Hamid, Z., Budin, S.B., Ng, W.J., Hamid, A., Husain, K. \& Mohamed, J. 2012. Nephroprotective effects of Zingiber zerumbet Smith ethyl acetate extract against paracetamolinduced nephrotoxicity and oxidative stress in rats. $J$. Zhejiang Univ. Sci.B. 13(3): 176-185.

Agrawal, D. \& Sultana, P. 1993. Biochemical and structural alterations in rat erythrocytes due to hexachlorocyclohexane exposure. Food Chem. Toxicol. 31(6): 443-448.

Anderson, D. \& Phillips, B. 1999. Comparative in vitro and in vivo effects of antioxidants. Food Chem. Toxicol. 37(9-10): 1015-1025.

Hamid, A., Lee, L.S., Karim, S.R. \& Jufri, N.F. 2018. Hepatoprotective effects of zerumbone against paracetamolinduced acute hepatotoxicity in rats. Malays J. Med. Sci. 25(2): 64-71.

Banerjee, A., Kunwar, A., Mishra, B. \& Priyadarsini, K. 2008. Concentration dependent antioxidant/pro-oxidant activity of curcumin: Studies from AAPH induced hemolysis of RBCs. Chem. Biol. Interact. 174(2): 134-139.

Beyer, W.F. \& Fridovich, I. 1987. Assaying for superoxide dismutase activity: Some large consequences of minor changes in conditions. Anal. Biochem. 161(2): 559-566.

Bhatia, K., Elmarakby, A.A., El-Remessey, A. \& Sullivan, J.C. 2012. Oxidative stress contributes to sex differences in angiotensin II-mediated hypertension in spontaneously hypertensive rats. Am. J. Physiol. Regul. Integr. Comp. Physiol. 302(2): 274-282.

Bhuiyan, M.N.I., Chowdhury, J.U.\& Begum, J. 2009. Chemical investigation of the leaf and rhizome essential oils of Zingiber zerumbet (L.) Smith from Bangladesh. Bangladesh $J$. Pharmacol. 4(1): 9-12.

Chakraborthy, A., Ramani, P.I., Sherlin, H.J., Premkumar, P. \& Natesan, A. 2014. Indian J. Dent. Res. 25(4): 499-504.

Chong, C.L.G., Othman, F. \& Farida Hussan, K. 2018. Vascular protective effects of Morinda citrifolia leaf extract on postmenopausal rats fed with thermoxidized palm oil diet: Evidence at microscopic level. International Journal of Vascular Medicine 2018: Article ID. 6317434.

Cimen, M.Y. 2008. Free radical metabolism in human erythrocytes. Clin. Chim. Acta. 390(1-2): 1-11.

Clemens, M.R. \& Waller, H.D. 1987. Lipid peroxidation in erythrocytes. Chem. Phys. Lipids 45(2-4): 251-268.

da Silva, T.M., Pinheiro, C.D., Orlandi, P.P., Pinheiro, C.C. \& Pontes, G.S. 2018. Zerumbone from Zingiber zerumbet (L.) smith: A potential prophylactic and therapeutic agent against the cariogenic bacterium Streptococcus mutans. BMC Complementary and Alternative Medicine 18: 301.

Ellman, G.L. 1959. Tissue sulfhydryl groups. Arch. Biochem. Biophys. 82(1): 70-77.

Gaschlera, M.M. \& Stockwell, B.R. 2017. Lipid peroxidation in cell death. Biochemical and Biophysical Research Communications 482: 419-425

Hamid, A., Budin, S.B., Mohamed, R.A.P., Abd Manaf, N., Yuhana, N.Y., Husain, K., Abdul Hamid, Z. \& Mohamed, J. 2011. Role of oxidative stress in the protective effects of Zingiber zerumbet Smith ethyl-acetate extract against paracetamol-induced hepatotoxicity in Sprague-Dawley rats. Aust.J. Basic Appl.Sci. 5(8): 1519-1525.

Hattangadi, S.M. \& Lodish, H.F. 2007. Regulation of erythrocyte lifespan: Do reactive oxygen species set the clock? J. Clin. Investig. 117(8): 2075-2077.
Holland-Letz, T. \& Kopp-Schneider, A. 2015. Optimal experimental designs for dose-response studies with continuous endpoints. Arch. Toxicol. 89(11): 2059-2068.

Hossain, M.E., Bhattacharjee, S.C. \& Islam, M.D.E. 2005. Chemical investigation on Zingiber zerumbet. Fron. Nat. Prod. Chem. (1): 185-187.

Hunter, M.I.S. \& Mohamed, J. 1986. Plasma antioxidants and lipid peroxidation products in Duchenne muscular dystrophy. Clin. Chim. Acta 155(2): 123-131.

Jang, D.S., Min, H.Y., Kim, M.S., Han, A.R., Windono, T., Jeohn, G.H., Kang, S.S., Lee, S.K. \& Seo, E.K. 2005. Humulene derivatives from Zingiber zerumbet with the inhibitory effects on lipopolysaccharides-induced nitric oxide production. Chem. Pharm. Bull. 53(7): 829-831.

Kamboj, V.P. 2000. Herbal medicine. Curr. Sci. 78(1): 35-39.

Kiruthiga, P., Shafreen, R.B., Pandian, S.K. \& Devi, K.P. 2007. Silymarin protection against major reactive oxygen species released by environmental toxins: Exogenous $\mathrm{H}_{2} \mathrm{O}_{2}$ exposure in erythrocytes. Basic Clin. Pharmacol. Toxicol. 100(6): 414-419.

Konyalioglu, S. \& Karamenderes, C. 2005. The protective effects of Achillea L. species native in Turkey against $\mathrm{H} 2 \mathrm{O} 2$-induced oxidative damage in human erythrocytes and leucocytes. $J$. Ethnopharmacol. 102(2): 221-227.

Lawrence, R.A. \& Burk, R.F. 1976. Glutathione peroxidase activity in selenium-deficient rat liver. Biochem. Biophys. Res. Commun. 71(4): 952-958.

Levine, R.L., Garland, D., Oliver, C.N., Amici, A., Climent, I., Lenz, A.G., Ahn, B.W., Shaltiel, S. \& Stadtman, E.R. 1990. Determination of carbonyl content in oxidatively modified proteins. Methods in Enzymology 186: 464-478.

Nag,A., Bandyopadhyay, M.\& Mukherjee,A. 2013.Antioxidant activities and cytotoxicity of Zingiber zerumbet (L.) Smith rhizome. J. Pharmacogn. Phytochem. 2(3): 102-108.

Nagababu, E., Chrest, F.J. \& Rifkind, J.M. 2003. Hydrogenperoxide-induced heme degradation in red blood cells: The protective roles of catalase and glutathione peroxidase. Biochim. Biophys. Acta 1620(1-3): 211-217.

Okoko, T. \& Ere, D. 2012. Reduction of hydrogen peroxideinduced erythrocyte damage by Carica papaya leaf extract. Asian Pacific Journal of Tropical Biomedicine 2(6): 449-453.

Qasim,N.\& Mahmood, R.2015. Diminution of oxidative damage to human erythrocytes and lymphocytes by creatine: Possible role of creatine in blood. Plos ONE 10(11): e0141975.

Rashid, R.A. \& Pihie, A.L. 2005. The antiproliferative effects of Zingiber zerumbet extracts and fractions on the growth of human breast carcinoma cell lines. Malays J. Pharm. Sci. 3(1): 45-52.

Ruslay, S., Abas, F., Shaari, K., Zainal, Z., Maulidiana, Sirat, H., Israf, D.A. \& Lajis, N.H. 2007. Characterization of the components present in the active fractions of health gingers (Curcuma xanthorrhiza and Zingiber zerumbet) by HPLCDAD-ESIMS. Food Chem. 104(3): 1183-1191.

Sen, S., Chakraborty, R., De, B.\& Mazumder, J. 2009. Plants and phytochemicals for peptic ulcer: An overview. Pharmacogn. Rev. 3(6): 270.

Somchit, M.N. \& Shukriyah, M.H.N. 2003. Anti inflammatory property of ethanol and water extracts of Zingiber zerumbet. Indian J. Pharmacol. 35(3): 181-182.

Srour, M.A., Bilto, Y.Y., Juma, M. \& Irhimeh, M.R. 2000 Exposure of human erythrocytes to oxygen radicals causes loss of deformability, increased osmotic fragility, lipid peroxidation and protein degradation. Clin. Hemorheol. Microcirc. 23(1): 13-21. 
Taib, I.S., Budin, S.B., Ain, S.M.S.N., Mohamed, J., Louis, S.R., Das, S., Sallehudin, S., Rajab, N.F. \& Othman, H. 2009. Toxic effects of Litsea elliptica Blume essential oil on red blood cells of Sprague-Dawley rats. J. Zhejiang. Univ. Sci. 10(11): 813 .

Tavazzi, B., Di Pierro, D., Amorini,A.M., Fazzina, G., Tuttobene, M., Giardina, L.G. 2000. Energy metabolism and lipid peroxidation of human erythrocytes as a function of increased oxidative stress. FEBS J.267(3): 684-689.

Tedesco, I., Russo, M., Russo, P., Iacomino, G., Russo, G.L., Carraturo, A., Faruolo, C., Moio, L. \& Palumbo, R. 2000. Antioxidant effect of red wine polyphenols on red blood cells. J. Nutri. Biochem. 11(2): 114-119.

Touriño, S., Lizárraga, D., Carreras, A., Matito, C., Ugartondo, V., Mitjans, M., Centelles, J., Vinardell, M., Juliá, L. \& Cascante, M. 2008. Antioxidant/prooxidant effects of bioactive polyphenolics. Elect.J.Environ.Agric. Food Chem. 7(8): 3348-3352.

Mohd Fuad Rahmat Sam, Asmah Hamid, Ahmad Rohi Ghazali \& Siti Balkis Budin*

Programme of Biomedical Science

Centre of Applied and Health Sciences

Faculty of Health Sciences

Universiti Kebangsaan Malaysia

Jalan Raja Muda Abdul Aziz

50300 Kuala Lumpur, Federal Territory

Malaysia
Mohd Fuad Rahmat Sam

Department of Biomedical Science

Kulliyyah of Allied Health Sciences

International Islamic University Malaysia, Jalan Istana 25200 Kuantan, Pahang Darul Makmur

Malaysia.

Santhana Raj Louis

Unit of Electron Microscope

Institute for Medical Research, Jalan Pahang 50588 Kuala Lumpur, Federal Territory

Malaysia

*Corresponding author; email: balkis@ukm.edu.my

Received: 30 March 2018

Accepted: 28 January 2019 